\title{
Author Correction: A dynamic code for economic object valuation in prefrontal cortex neurons
}

\author{
Ken-Ichiro Tsutsui, Fabian Grabenhorst, Shunsuke Kobayashi \& Wolfram Schultz
}

Nature Communications 7:12554 doi: 10.1038/ncomms12554 (2016); Published 13 Sep 2016; Updated 23 Nov 2017.

The previously published version of this Article contained an error in Figure 1 . In panel $\mathrm{b}$ the $x$ and $y$ axis labels of the scatter graph were inadvertently inverted. This error has been corrected in both the PDF and HTML versions of the Article.

\begin{abstract}
(c) (i) Open Access This article is licensed under a Creative Commons Attribution 4.0 International License, which permits use, sharing, adaptation, distribution and reproduction in any medium or format, as long as you give appropriate credit to the original author(s) and the source, provide a link to the Creative Commons license, and indicate if changes were made. The images or other third party material in this article are included in the article's Creative Commons license, unless indicated otherwise in a credit line to the material. If material is not included in the article's Creative Commons license and your intended use is not permitted by statutory regulation or exceeds the permitted use, you will need to obtain permission directly from the copyright holder. To view a copy of this license, visit http://creativecommons.org/licenses/by/4.0/
\end{abstract}

(C) The Author(s) 2017 